skiego - Arturo Sacchetti. Jego ideą było zebrać organistów, chórmistrzów, liturgistów, kompozytorów itd. - o „ile jeszcze tacy istnieją”, jak nadmienił przewodniczący, aby zdrowo popatrzeć na rzeczywistość muzyczną, w której żyjemy. Kongres postawił sobie wzniosły cel - uwrażliwienie ludzi muzyki na konsekwencje wynikające z braku twórczego wysiłku i wychowania liturgiczno-muzycznego kapłanów, kleryków, organistów i wiernych. zanika wiele dawnych zawodów, które uwrażliwialy na piękno i wartości muzyki, dając dobre przygotowanie warsztatowe i artystyczne. Aby liturgia mogła być godnie sprawowana - ciągle podkreślano - potrzebne jest zrozumienie i jak najlepsze przygotowanie na tyle, na ile człowiek jest zdolny twórczo sprawować i uczestniczyć w obrzędach liturgicznych.

W obradach kongresu poruszono również problem języka włoskiego - czego nie zauważa się w naszym języku. Każdy region Włoch posługuje się swoistym dialektem i te naleciałości językowe weszły też w zakres wymowy i słownictwa liturgicznego - co oczywiście jest nie do przyjęcia. Stworzono więc pewne zasady co do prawdziwego przekazu liturgii; wydano specjalny podręcznik Poprawna wymowa języka wtoskiego wprawdzie w małym nakładzie, ale jest to już pewien krok unifikacji modlitwy liturgicznej. Zwrócono uwagę na konieczność dalszego kształcenia lektorów, animatorów, komentatorów, kantorów, którzy są zobowiązani wziąć udział w specjalnych kursach szkoleniowych z dziedziny muzyki liturgicznej.

Szczegółowy program kongresu był dość bogaty. Wygłoszono 7 referatów, a do ciekawszych należały: P. S a n tu cci, Problemy kompozytorskie $i$ wykonawcze w liturgii posoborowej; G. Paiu sco, Kościót i Państwo przed dziedzictwem kultury organowej wtoskiej (prawo, opieka); A. S a cch et ti, Historia muzyki organowej dawnej $i$ wspótczesnej $i$ wzajemne ich relacje; V. Mise rachs, Tradycja polifoniczna „Liberiana”.

W pierwszym dniu kongresu była okazja wysłuchania koncertu organowego mistrza Arturo Sacchetti w ciekawej muzyce: Bossi, Manari, Ravanello, Perosi. Koncert miał miejsce w kościele Matki Bożej in Traspontina, przy Watykanie. W drugim dniu natomiast prezentowała się Capella „Liberiana” z bazyliki S.M. Maggiore z programem utworów maryjnych. Był to historyczny przegląd twórczości kapelmistrzów „Liberiana” istniejącej już od XVI w., której m.in. kierownikiem był G. Palestrina w latach 15611565.

Organizacja samego kongresu była na wysokim poziomie, jedynie zawiodła frekwencja. Mimo ogłoszeń w radio, biuletynach i na tysiąc imiennych zaproszeń rozesłanych przez organizatorów kongresu przybyło zaledwie dziesięć osób - w tym niżej podpisany.

Łódż-Panewniki O. RYSZARD PAROL OFMConv.

\title{
175 LAT BRYTYJSKIEGO I ZAGRANICZNEGO TOWARZYSTWA BIBLIJNEGO W POLSCE
}

W dniach od 13. do 15. września 1991 r. odbyła się w Nadarzynie k. Warszawy sesja jubileuszowa z okazji 175-lecia istnienia Brytyjskiego i Zagranicznego Towarzystwa Biblijnego w Polsce pod hasłem: „Biblia w Europie dzisiaj”. Oprócz gości z Polski reprezentujących wszystkie Kościoły w sesji wzięło udział 36 przedstawicieli Towarzystw Biblijnych z zagranicy reprezentujących 18 krajów.

Referat zasadniczy „Biblia w obecnej sytuacji w Europie” wygłosił przewodniczący Zjednoczonych Towarzystw Biblijnych biskup ewang. Eduard Lohse.

Drugi referat pt. „Rola i zadania Apostolatu Biblijnego w reewangelizacji Europy w okresie posttotalitaryzmu" przedstawił biskup Alberto Ablondi, przewodniczący Federacji ds. Apostolatu Biblijnego i wiceprzewodniczący Zjednoczonych Towarzystw Bi- 
blijnych. „Rolę i zadania Biblii w reewangelizacji posttotalitarnej Europy z perspektywy Kościoła rzymskokatolickiego w Polsce" omówił w swoim wystąpieniu biskup Kazimierz Romaniuk. „Rolę i zadania Biblii w reewangelizacji posttotalitarnej Europy z perspektywy Kościołów w Rosji" przedstawił ks. prof. Konstantine Logachev z St. Petersburga (Kościół prawosławny). „Rolę i zadania Biblii w reewangelizacji posttotalitarnej Europy z perspektywy Kościołów w Czecho-Słowacji” prezentował pastor dr Jiry Lukl. „Biblia w Europie dzisiaj" była przedmiotem wystąpienia pastora S. Mydske z Norwegii. Po wygłoszonych referatach odbyła się dyskusja.

Na specjalnej audiencji kierownictwo Towarzystw Biblijnych i gości z zagranicy przyjął Ks. Kardynał Józef Glemp, Prymas Polski. W swoim wystąpieniu, odwołując się do rozpoczętego Synodu Kościoła katolickiego w Polsce, Ks. Prymas wskazał na znaczenie Biblii w życiu rodziny chrześcijańskiej. Dyrektor Towarzystwa w Polsce Barbara Enholc-Narzyńska wręczyła Ks. Prymasowi nowo wydany egzemplarz Pisma Św. z księgami apokryficznymi z „Biblii Tysiąclecia”, który właśnie ukazał się w druku, serdecznie dziękując za możliwość jego wydania za zgodą Konferencji Episkopatu Polski, Podkomisji Biblijnej z jej przewodniczącym biskupem Kazimierzem Romaniukiem. Jest to pierwsze wydanie Pisma Świętego przygotowane we współpracy z Kościołem katolickim w Polsce, jak również pierwsze wydanie od 1947 roku Pisma Świętego z księgami deuterokanonicznymi przygotowane przez Brytyjskie i Zagraniczne Towarzystwo Biblijne w Polsce. Biskup Alberto Ablondi, przewodniczący Federacji ds. Apostolatu Biblijnego i wiceprzewodniczący Zjednoczonych Towarzystw Biblijnych podkreślił w swoim wystąpieniu u Ks. Prymasa rozwijające się i pogłębiające związki pomiędzy Zjednoczonymi Towarzystwami Biblijnymi i Federacją. Rośnie i pogłębia się rola pracy międzykonfesyjnej poprzez wzrastającą liczbę wspólnych przekładów Pisma Ŝw. W szczególny sposób dotyczy to krajów postsocjalistycznych i Wschodniej Europy, gdzie współpraca taka rośnie, jest żywa i pragniemy, aby się nadal rozwijała, czego przykładem jest spotkanie w Polsce. Wszystko jest w ręku Ducha Św., któremu winny dopomagać Kościoły i Towarzystwa Biblijne poprzez wspólne działanie wielu ludzi dobrej woli z różnych Kościołów.

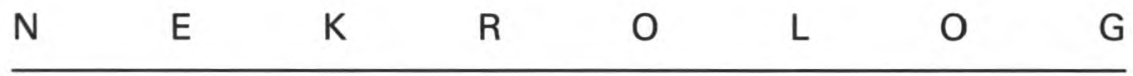

Ks. Marian Wolniewicz

\section{ŚP. KS. FELICJAN KŁONIECKI (1909-1990)}

W sobotę, dnia 27 października 1990 roku o godzinie 6-tej zmarł w Gnieźnie ks. infulat Felicjan Kłoniecki protonotariusz apostolski i dziekan Prymasowskiej Kapituły Katedralnej, a zarazem długoletni profesor nauk biblijnych w Prymasowskim Wyższym Seminarium Duchownym w Gnieźnie. Ciało jego złożono do grobu na gnieźnieńskim cmentarzu św. Piotra.

Felicjan, syn Mikołaja Kłonieckiego i Teofili Pelagii z d. Gordon, urodził się dnia 28 maja 1909 roku w Osowcu, pow. Bydgoszcz.

Po maturze uzyskanej w 1928 roku w bydgoskim gimnazjum klasycznym dawnego typu zostal przyjęty do Arcybiskupiego Seminarium Duchownego w Gnieźnie na studia 